\title{
THE STUDY OF QUALITY AND SAFETY PARAMETERS OF THE SPECIAL VODKA OF NATIVE PRODUCTION
}

\author{
Olena Kalashnik \\ Department of Expertise and Custom Affair \\ HEI CACCU "Poltava University of Economy and Trade" \\ 3 Koval str., Poltava, Ukraine, 36014 \\ kalashyik1968@meta.ua \\ Nadia Remisova \\ SE "Poltavastandardmetrology" \\ 6 Vuzka str., Poltava, Ukraine, 36022 \\ Remizo2p@rambler.ru \\ Zoya Rachinska \\ Department of Expertise and Custom Affair \\ HEI CACCU "Poltava University of Economy and Trade" \\ 3 Koval str., Poltava, Ukraine, 36014 \\ marta00.87@mail.ru
}

\begin{abstract}
Insofar as country is in unstable situation, many goods and products of the low quality and falsified ones appeared on the native market. Excise alcohol production is the most beneficial for falsification, because its profitability is very high.

Among alcohol drinks vodka stays the most popular one that is produced in large scales. Last time the consumption of alcohol drinks increased by $22 \%$, so, the efforts of consumption policy must be directed on the rise of culture of drinking behavior and prophylaxis strategy.

The parameters of quality and safety of the special vodka of TM "Home rye pervak" are studied. The normative documents that regulate quality of the special vodka in Ukraine are analyzed. There were studied organoleptic, physical-chemical parameters and safety of the special vodka of TM "Home rye pervak" made by LTD "UDK" (Poltava, Ukraine).

It was established, that special vodka of TM "Home rye pervak" made by Ukrainian producer "UDK" corresponds to all requirements of the national standard of Ukraine as to physical-chemical parameters and the ones of safety.
\end{abstract}

Keywords: vodka, quality, safety, strength, alkalinity, aldehydes, fusel oils, esters, alcohol.

\section{Introduction}

For today there is a possibility to create the civilized goods market that would develop the economy of Ukraine. The internal Ukrainian market is filled with wide spectrum of goods of the native and foreign production that leads to decrease of pressure of consumer demand. In these conditions the need to improve the quality of production, to require safe and harmless production for consumers increases.

These scientists studied the parameters of safety and quality of vodka in Ukraine [1-7].

The problem of quality and safety of food products is certainly the one most important for consumers. According to the article 1 of the Law of Ukraine "On the main principles and requirements to the quality and safety of food products" [8] food product is considered as unacceptable for consumption by human, if it, among the other, does not correspond to the obligatory minimal specifications of quality.

The producers of alcoholic products in Ukraine try to improve the quality of their production by the different ways: use different components that soften taste; purify both the ready product and its components; prepare water by the different ways and so on. But vodka is assigned to the most often falsified group of alcoholic products, because it is easy in production and is in demand among consumers. 
Falsification of vodka quality is attained by the spread and specific ways by adding water; introduction of substances, not provided by recipe; full or partial replacement of ethanol by technical alcohol; use of the water that does not fit for preparation of alcoholic products. That is why the study of parameters of quality and safety of such food product as special vodka is timely and urgent.

The object of research is the special vodka of TM "Home rye pervak" of the first distillation made by "UDK" LTD (Poltava). Characteristics of the object of research: volume - 0,5 L, strength $-40 \%$.

The realized researches were aimed at comprehensive, complex study and determination of the main parameters of quality of special vodka of TM "Home rye pervak" for determination of the level of its quality and safety and also the correspondence of requirements of normative documentation [9].

\section{Materials and methods of research}

The assessment of physical-chemical quality parameters of the special vodka of TM "Home rye pervak" was realized by the standard methods according to SSTU "Vodkas and special vodkas. Rules of taking and methods of testing" [10].

Content of heavy metals was determined by voltammetric method.

\section{1. Experimental procedures}

For assessment of physical-chemical quality parameters of the special vodka of TM "Home rye pervak", made of alcohol "Lux", were chosen such parameters as strength, alkalinity, mass concentration of aldehydes, mass concentration of fusel oil, mass concentration of esters, volume part of methyl alcohol.

The content of alcohol is determined by dependence of its concentration from the relative density of solution that is determined by aerometric method using the glass alcoholmeter (Fig. 1).

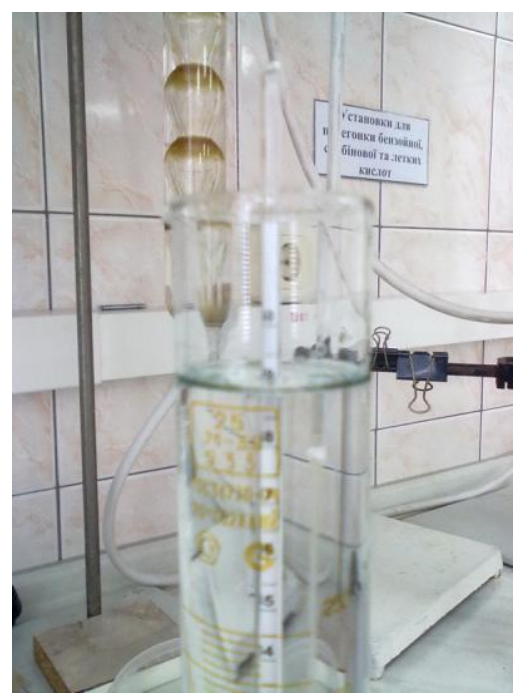

Fig. 1. Determination of strength of vodka of TM "Pervak" with help of glass alcoholmeter

Alkalinity of vodka was determined in such a way - sample of vodka of $100 \mathrm{~cm}^{3}$ was placed in conical flask of $250 \mathrm{~cm}^{3}$ and was titrated in solution of methyl red by solution of hydrochloric acid with concentration $0,1 \mathrm{~mol} / \mathrm{dm}^{3}$ up to coloration of yellow tint of solution in orange rose one (the start of coloration) (Fig. 2).

The final result of analysis was considered as arithmetical mean of the results of two parallel values that are approximated to the first decimal digit.

Mass concentration of aldehydes in recalculation on acetic aldehyde in absolute alcohol in vodka was determined by the method that is grounded on reaction of alehydes, present in studied vodka, with fuchsin-sulfuric reagent (Fig. 3). 

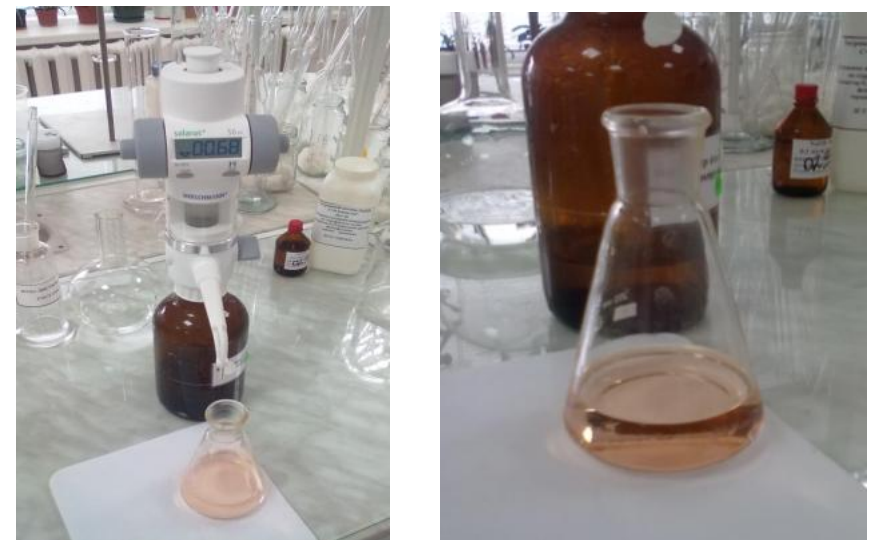

Fig. 2. Determination of alkalinity of special vodka of TM "Pervak"

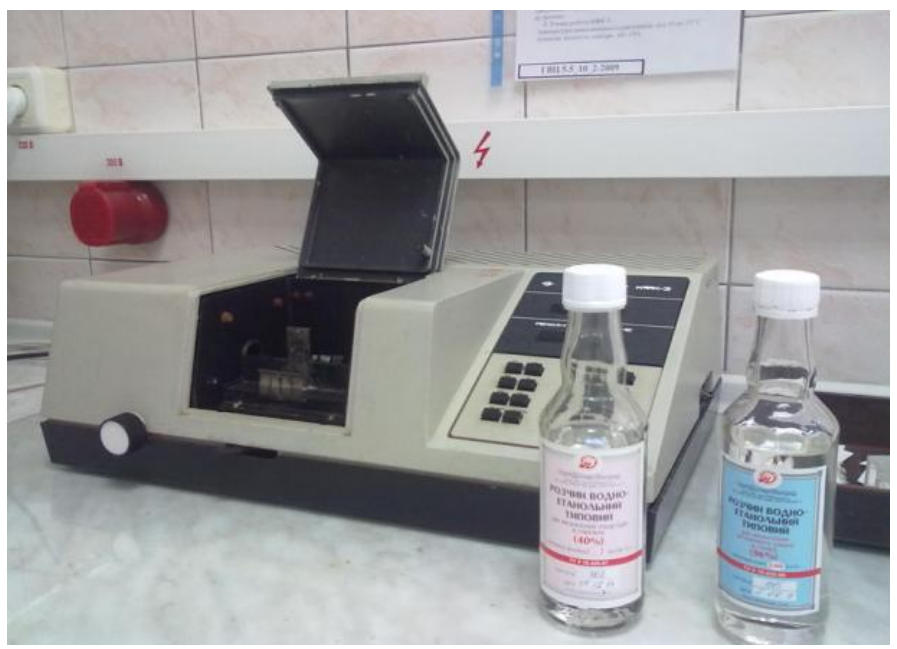

Fig. 3. Determination of mass concentration of aldehydes in special vodka of TM "Pervak"

Mass concentration of fusel oil in recalculation on mixture of isoamyl and isobutyl alcohols (1:1) in absolute alcohol was determined by reaction of fusel oil with salicylic aldehyde at presence of concentrated sulfuric acid using photoelectrocolorimeter.

Mass concentration of esters in recalculation on acetic-ethyl ester in absolute alcohol was determined with help of photoelectrocolorimetric method that is grounded on determination of intensity of coloration after reaction of ferric chloride (III) hexahydrate with hydroxamic acid, formed as a result of contact of esters of studied vodka with muriatic hydroxylamine in alkaline medium, and also gas chromatographic method.

The volume part of methyl alcohol in recalculation on absolute alcohol in vodka was determined by photoelectrocolorimetrc method that is grounded on measurement of intensity of coloration as a result of contact of disodium salt of chromotropic acid (1,8-dioxy-naphthalene-3,6-disulfonic acid) with formaldehyde that is formed as a result of acidation of methyl alcohol, contained in studied vodka, by potassium permanganate.

The content of heavy metals was determined with the help of voltammetric method that is grounded on registration and study of dependence of voltage that flows through electrolytic focus from external superimposed voltage.

Graphic presentation of this dependence (voltammetrogram) shows peaks of voltage, which place on axis of potentials is a quality characteristics and height of peak, proportional to ions concentration in solution, is a quantity characteristics. 

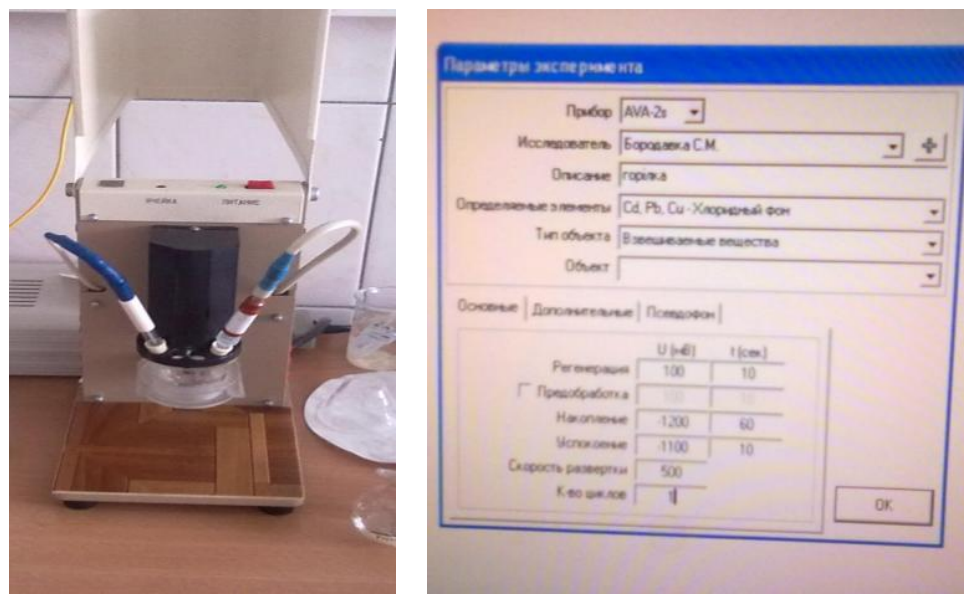

Fig. 4. Determination of content of heavy metals in special vodka of TM "Pervak"

\section{Results of research}

The results of research of physical-chemical quality parameters of the special vodka of TM "Home rye pervak" by the standard methods are presented in the Table $\mathbf{1 .}$

\section{Table 1}

Results of research of physical-chemical quality parameters of the special vodka of TM "Home rye pervak"

\begin{tabular}{lcc}
\hline \multicolumn{1}{c}{ Name of parameter } & $\begin{array}{c}\text { Requirements according to } \\
\text { SSTU 4256:2003 }\end{array}$ & $\begin{array}{c}\text { Value of } \\
\text { received results }\end{array}$ \\
\hline Strength, $\%$ & $37,5-56,0$ & 39,8 \\
Alkalinity, $\mathrm{cm}^{3}$, not more than & 3,5 & 0,68 \\
$\begin{array}{l}\text { Mass concentration of aldehydes in recalculation on acetic aldehyde in absolute } \\
\text { alcohol, } \mathrm{mg} / \mathrm{dm}^{3} \text {, not more than }\end{array}$ & 6,0 & 2,7 \\
$\begin{array}{l}\text { Mass concentration of fusel oil in recalculation on mixture of isoamyl and } \\
\text { isobutyl alcohols }(1: 1) \text { in absolute acid, mg/dm }{ }^{3} \text {, not more than }\end{array}$ & 3,0 \\
$\begin{array}{l}\text { Mass concentration of esters in recalculation on acetic-ethyl ester in absolute } \\
\text { alcohol, } \mathrm{mg} / \mathrm{dm}^{3} \text {, not more than }\end{array}$ & 7,0 & 0,7 \\
Volume part of methyl alcohol in recalculation on absolute alcohol, \%, not more than & 0,01 & 1,0
\end{tabular}

Analysis of voltammerograms of the sample of special vodka of TM "Home rye pervak" gives information about qualitative and quantitative content of analyzed solution (Fig. 5).

Results of measurements are given in the Table 2.

Table 2

Heavy metals content in special vodka of TM "Home rye pervak"

\begin{tabular}{ccc} 
Heavy metals & Allowable level, $\mathbf{~ m g} / \mathbf{k g}, \mathbf{n o t}$ more than & Values of received results, $\mathbf{~ m g} / \mathbf{k g}$ \\
\hline Cadmium & 0,03 & $\mathbf{0 , 0 1 3 4}$ \\
Copper & 5,0 & $\mathbf{0 , 0 5 3 9}$ \\
Lead & 0,3 & $\mathbf{0 , 0 2 9 8}$ \\
Zinc & 10,0 & $\mathbf{0 , 8 5 4 0}$
\end{tabular}


The special vodka of TM "Home rye pervak" corresponds to the requirements of SSTU 4256:2003 as to the heavy metals content [9].
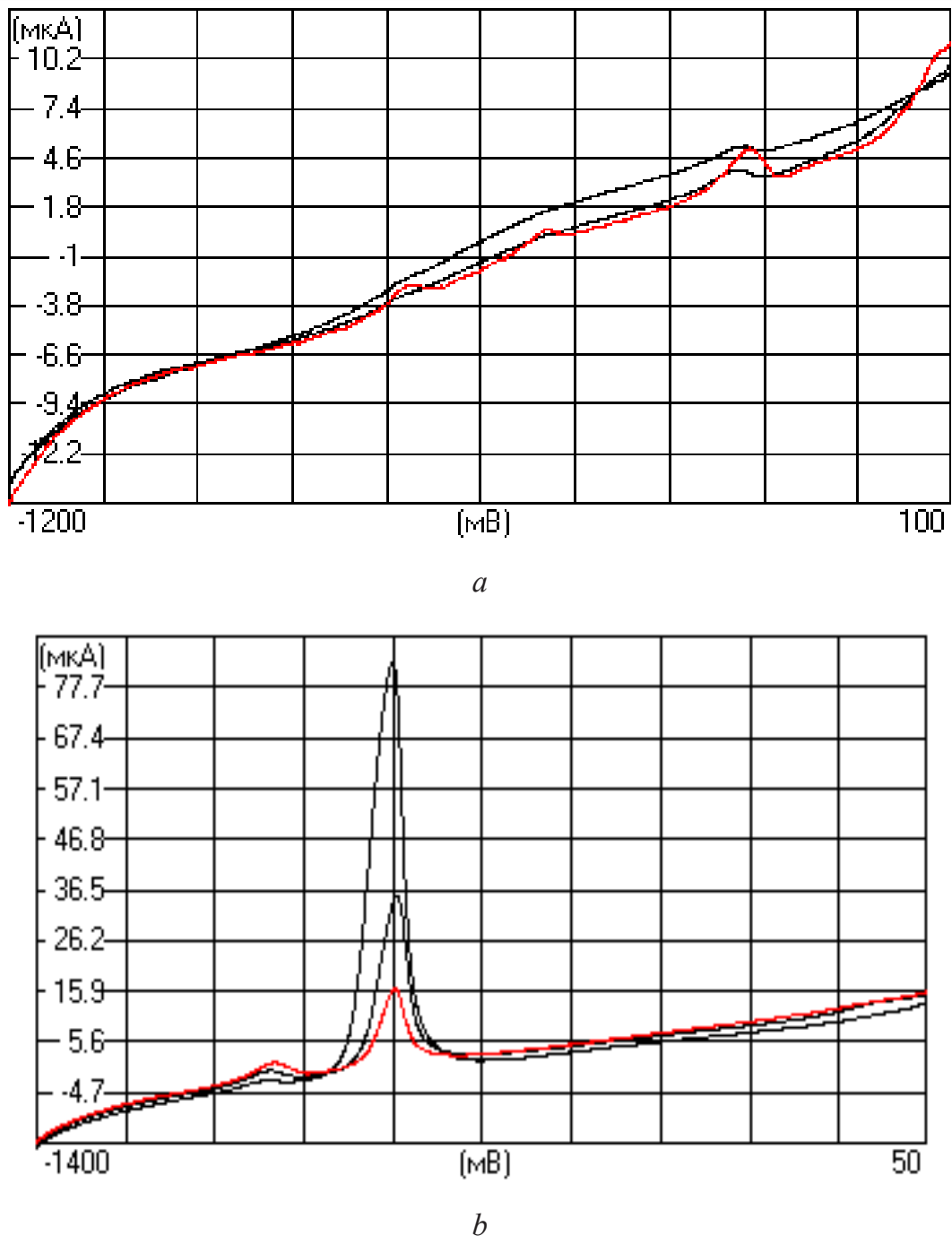

Fig. 5. Voltammetrograms of the heavy metals content in special vodka of TM "Home rye pervak": $a$ - cadmium, lead, copper; $b$ - zinc

\section{Conclusions}

1. It was established, that Ukrainian producer "UDK" LTD of the special vodka of TM "Home rye pervak" corresponds to all accepted requirements as to packaging and marking, provided by SSTU 4256:2003 [9].

2. The researches elucidated that the special vodka of TM "Home rye pervak" made by "UDK" LTD corresponds to requirements, provided by SSTU 4256:2003 by physical-chemical quality parameters (strength, alkalinity, mass concentration of aldehydes, mass concentration of fusel oils, mass concentration of esters, volume part of methyl alcohol) and by safety parameters (cadmium, copper, lead, zinc content) [9].

It can be stated, that this product, chosen as object of research, is high-quality and safe for consumption.

\section{Acknowledgment}

The authors are grateful to Borodavka S. N. for the assistance in preparing and carrying out the experiment. 


\section{References}

[1] Onosova, I. A. (2012). Doslidzhennja vmistu mineraljnykh domishok i jikhnjogho vplyvu na jakistj ghorilky, shho realizujetjsja na rynku Ukrajiny. Zbirnyk naukovykh pracj «Proghresyvna tekhnika ta tekhnologhiji kharchovykh vyrobnyctv restorannogho ghospodarstva i torghivli», 2 (16), 190-198.

[2] Kuzjmin, O. V., Onosova, I. A., Lovjaghin, O. M. (2011). Zaghaljna klasyfikacija kharchovykh dobavok, shho vykorystovujutjsja u vyrobnyctvi ghorilok. "Obladnannja ta tekhnologhiji kharchovykh vyrobnyctv”. Tematychnyy zbirnyk naukovykh prats' Donets'koho natsional'noho universytetu ekonomiky i torhivli imeni M. Tuhan-Baranovs'koho, 27, 332-340.

[3] Lovjaghyn, A. N., Shevchenko, L. A., Kovaljchuk, V. P. (2005). Prymenenye yonnoj khromatoghrafyy dlja izuchenyja stojkosty spyrtnikh napytkov. Zhurnal Khromatoghrafichnogho tovarystva, 5 (1), $2-28$.

[4] Omarov, V. O. (2011). Udoskonalennja metodyky vyznachennja vmistu aljdeghidiv u ghorilci osoblyvij dlja vyjavlennja jiji faljsyfikaciji. Moskva.

[5] Kovaljchuk, V. P., Olijnyk, S. I. (2008). Rozroblennja ta vprovadzhennja novykh nacionaljnykh standartiv dlja vyrobnyctva likero-ghorilchanoji produkciji. Naukovi praci ONAKhT, 34, 226-230.

[6] Kovaljchuk, V. P., Olijnyk, S. I., Opanasjuk, T. I., Rezvina, L. M. (2002). Stijkistj i jakistj alkogholjnykh napojiv. Kharchova i pererobna promyslovistj, 8, 19-21

[7] Chepelj, N. (2012). Vykorystannja aromatyzatoriv u vyrobnyctvi osoblyvoji ghorilky «Kapitan». Available at: http://tr.knteu.kiev.ua/index.php?option=com_content\&view=article\&id=159:vikoristannya-aromatizatoriv-u-virobnitstvi-osoblivoji-gorilki-kapitan\&catid=43:2012-1\&lang=uk

[8] Zakon Ukrajiny. (2016). Available at: http://zakon0.rada.gov.ua/laws/main/771/97-вр

[9] DSTU 4256-2003 Horilky i horilky osoblyvi. Tekhnichni umovy. (2004). Available at: http:// www.twirpx.com/file/1658216/

[10] DSTU 4165:2003 Horilky i horilky osoblyvi. Pravyla pryymannya i metody vyprobuvannya. (2003). Available at: http://normativ.ucoz.org/load/dstu_4165_2003/3-1-0-568 